\title{
Morphogenetic characteristics of three Brachiaria brizantha cultivars submitted to nitrogen fertilization
}

\author{
MARCOS F. SILVA ${ }^{1}$, EDSON M.V. PORTO ${ }^{1}$, DORISMAR D. ALVES ${ }^{1}$, \\ CLÁUDIO M.T. VITOR ${ }^{2}$ and IGNACIO ASPIAZÚ ${ }^{1}$ \\ ${ }^{1}$ Universidade Estadual de Montes Claros (UNIMONTES), Departamento de Ciências Agrárias, \\ Avenida Reinaldo Viana, 2630, Bairro Bico da Pedra, 39440-000 Janaúba, MG, Brasil \\ ${ }^{2}$ Universidade Federal de São João Del-Rei (UFSJD), \\ Rodovia MG 424, Km 65, Zona Rural, 35701-970 Prudente de Morais, MG, Brasil
}

Manuscript received on April 20, 2011; accepted for publication on December 27, 2011

\begin{abstract}
This study aims to evaluate the morphogenetic characteristics of three cultivars of Brachiaria brizantha subjected to nitrogen fertilization. The design was a randomized block in factorial arrangement $4 \times 3$; three cultivars of B. brizantha - Marandu, Piatã, Xaraés and four nitrogen levels - 0, 80, 160 and $240 \mathrm{~kg} / \mathrm{ha}$, with three replications. The experimental units consisted of plastic pots filled with $5 \mathrm{dm}^{3}$ of soil. Thereupon the establishment fertilization, varieties were sowed directly in the pots, leaving, after thinning, five plants per pot. Forty-five days after planting, it was done a standardization cut at $10 \mathrm{~cm}$ tall. Nitrogen levels were distributed according to the treatments, divided in three applications. The morphogenetic characteristics were evaluated in three tillers per sampling unit and data were submitted to analysis of variance and regression. For all evaluated characteristics there was no interaction between factors cultivar and nitrogen levels, verifying only the effects of nitrogen on the variables leaf appearance rate and phyllochron. The dose $240 \mathrm{~kg} / \mathrm{ha}$ of N corresponds to the greater leaf appearance rate. Cultivar Marandu shows the higher leaf blade: pseudostem and ratio of leaf elongation rate and elongation pseudostem, which favors higher forage quality.
\end{abstract}

Key words: cv. Marandu, cv. Piatã, cv. Xaraés, morphogenesis, signal grass.

\section{INTRODUCTION}

Productivity and perennial characteristics of pastures are generally associated with the availability of a range of biotic and abiotic factors that correlate, forming a complex ecosystem, where genetic factors, soil, climate, fertility and pasture management determine its balance and avoid a possible degradation, regarding to the provision of necessary inputs for their growth.

Correspondence to: Dorismar David Alves

E-mail: dorismar.alves@unimontes.br
In order to increase the efficiency of livestock industry, comes the demand for generation and diffusion of new technologies that will facilitate better understanding of forage plants. In this context, comes the morphogenesis, that can be defined as the dynamic of generation and expansion of the plant shape in space (Chapman and Lemaire 1993), becoming an important tool for the establishment of grazing management strategies, aiming at improving utilization. 
Among the management strategies used to improve the efficiency of forage production, pasture fertilization stands out, mainly with nitrogen, through the significant increase in the tissues flow (Duru and Ducrocq 2000) and longevity of plants, in which nitrogen has great importance due to its complexity in the grazing land ecosystem, requiring more results in its effect on the generation and expansion of plant organs.

Among the forage species used for pasture establishment, those of the Brachiaria genus stand out, occupying $70 \%$ to $80 \%$ of cultivated grazing land areas (Valle et al. 2001), where the grasses of this genus are adapted to different soil conditions and climate.

Despite the existence of some results on morphogenic evaluations for this species, the researches continuity becomes important to the formation of stronger scientific basis about management of this species. In recent years, aiming the objective of diversification of grasslands in Brazil, the Empresa Brasileira de Pesquisa Agropecuária - Gado de Corte (EMBRAPA - Beef Cattle) released two new genotypes of Brachiaria brizantha (cvs Xaraés and Piatã) as an option for implementation of pastures. However, there are few studies on the morphogenesis of these genotypes.

With that in mind, it is proposed to generate information about the morphogenesis of three $B$. brizantha cultivars, providing subsidies to a more appropriate management of these grasses.

\section{MATERIALS AND METHODS}

The experiment was conducted in a greenhouse at the Gorutuba Experimental Farm, EPAMIG-URENM, located in Nova Porteirinha, a city bordering Janaúba, situated in the northern region of Minas Gerais, $15^{\circ}$ $47^{\prime}$ South, $43^{\circ} 18^{\prime}$ West and $516 \mathrm{~m}$ altitude, in the period of September 2008 to May 2009.

The experiment was conducted according to a randomized block design with three replications, in which the samples were constituted of plastic pots with a capacity of $5 \mathrm{dm}^{3}$ of soil. The treatments were distributed in a factorial $(3 \times 4)$ corresponding to three cultivars of the species Brachiaria brizantha (B. brizantha cv. Marandu, B. brizantha cv. Piatã and $B$. brizantha cv. Xaraés) and four nitrogen levels $(0,80,160$ and $240 \mathrm{~kg} / \mathrm{ha})$, totaling 36 experimental units.

The soil was classified as an eutrophic Red Latosol, collected under typical region vegetation, in a 0 to $20 \mathrm{~cm}$ depth, with the following analytical results: $\mathrm{Al}^{3+}=0.0, \mathrm{Ca}^{2+}=0.6$ and $\mathrm{Mg}^{2+}=0,2 \mathrm{cmol}_{\mathrm{c}} /$ $\mathrm{dm}^{3}, \mathrm{~K}^{+}=73 \mathrm{cmol}_{\mathrm{c}} / \mathrm{dm}^{3}, \mathrm{P}=9.3 \mathrm{mg} / \mathrm{dm}^{3}$; clay $=21$; silt $=35$ and sand $=44 \mathrm{~g} / \mathrm{kg}$, respectively, and $\mathrm{pH}$ (water) $=5.0$; organic matter $=0.6 \mathrm{dag} / \mathrm{kg}$ and base saturation $(\mathrm{V} \%)=24$.

The collected soil was dried in the shade, loosened and sieved $(6 \mathrm{~mm})$, and then the liming was carried out, applying a dose of $3 \mathrm{~g}$ of calcined limestone (Neutralization Potential, NP $=123.38$ $\%)$ per pot, which is necessary for raising base saturation to $60 \%$, remaining for 30 days in incubation. Right after this incubation period, it was performed an establishment fertilization with $90 \mathrm{~kg} / \mathrm{ha}$ of $\mathrm{P}_{2} \mathrm{O}_{5}, 30 \mathrm{~kg} / \mathrm{ha}$ of $\mathrm{KCl}$ and $50 \mathrm{~kg} / \mathrm{ha}$ of FTE BR-16, according to the criteria used for the Soil Fertility Commission of the State of Minas Gerais (CFSEMG 1999).

After the establishment fertilization, the species were sowed in the pots at a depth of $1 \mathrm{~cm}$, using a slight excess of seeds in order to obtain an adequate plant stand.

In the first 15 days after germination, three thinnings were carried out until there were only five plants per pot. At 45 days after planting, all plants were clipped $10 \mathrm{~cm}$ above the ground (standardization cut). Nitrogen doses were distributed according to the treatments, and divided in three applications after the standardization cut, being made in each regrowth period (35 days interval) and using ammonium sulfate as nitrogen source.

Water control was made daily by keeping the soil with approximately $80 \%$ of its field capacity. 
Morphogenic evaluations were made at the beginning of each regrowth period (35 days interval). For that, three plants per pot were marked, randomly, receiving a different colored plastic ring in white, black and red to identify the tillers that were followed throughout the evaluation period, totalling three evaluation cuts, which stands for approximately 105 days.

The study of morphogenesis was performed twice a week, starting from the standardization cut throughout the whole experimental period, and the data registered on previously developed spreadsheets.

Leaf length was measured according to the stage of their development. For fully expanded leaves, it was measured the length of the leaf tip to ligule. In the case of expanding leaves, the same procedure was adopted, however, considering the ligule of the last fully expanded leaf as a reference for measurement. For the leaves in senescence, it was observed the difference between the final senescent length (yellowing and blackening) and initial senescent length. The size of the pseudostem was considered as the distance from the ground to the last fully expanded ligule.

From these data, estimations were made of:

a) Leaf appearance rate (LAR), in leaf/tiller/day: relationship between the number of emerged leaves per tiller and number of days of evaluation period;

b) Phyllochron: inverse of leaf appearance rate (days/leaf/tiller). Represents the average interval time for the appearance of successive leaves on each tiller.

c) Leaf elongation rate (LER), in cm/tiller/day: the difference between final length and initial length of expanding leaves, divided by the number of days between measurements.

d) Pseudostem elongation rate (PER), in cm/tiller/ day: relationship between the difference in the length of the pseudostem, final and initial, and the number of days of the evaluation period.

e) Leaf blade final length (LBFL), in $\mathrm{cm} /$ tiller: average length of leaf blades of all expanded leaves.
Data regarding the evaluated characteristics were subjected to regression analysis in function of nitrogen levels, and cultivars in function of the Tukey's test, selecting the equations by the coefficient of determination $\left(\mathrm{R}^{2}\right)$ and by the $5 \%$ significance of the coefficients, according to the $t$ test. The regression equations were adjusted based on treatment means.

\section{RESULTS AND DISCUSSIONS}

No interaction was observed $(\mathrm{P}>0.05)$ between the factors, $\mathrm{N}$ levels and the cultivar of the species $B$. brizantha, being verified only the isolated effects of nitrogen on the variables leaf appearance rate and phyllochron. For the variable leaf appearance rate, it was noted an effect of nitrogen fertilization and the equation that best fits the data is presented in Figure 1. The $240 \mathrm{~kg} / \mathrm{ha}$ level of $\mathrm{N}$ had the highest leaf appearance rate, corresponding to 0.70 leaves/day, showing an increase of $14 \%$ compared to $0 \mathrm{~kg} / \mathrm{ha}$ level of $\mathrm{N}$, which represented 0.60 leaves/day of leaf appearance rate. The effect of nitrogen fertilization on leaf appearance is found in literature in a quite variable way (Duru and Ducrocq 2000, Garcez Neto et al. 2002), which may be related to differences in the nitrogen levels among other factors.

According to Alexandrino et al. (2004), under greenhouse conditions, studying the morphogenesis of $B$. brizantha cv. Marandu subjected to three $\mathrm{N}$ levels and eight regrowth times, it was observed that increased $\mathrm{N}$ supply caused a positive increase of leaf appearance, with similar results to this work.

According to Nabinger and Pontes (2001), leaf appearance rate determines large differences in the structure of the pasture due to its effect on the size and number of tillers, which determines the direct relationship of leaf appearance rate with the tillering potential for a given genotype, i.e., the generation of new leaves per tiller.

As for the phylochron, it can be observed (Figure 2) that there was a pattern of behavior contrary to the variable leaf appearance rate in response to nitrogen rates, with declining values 


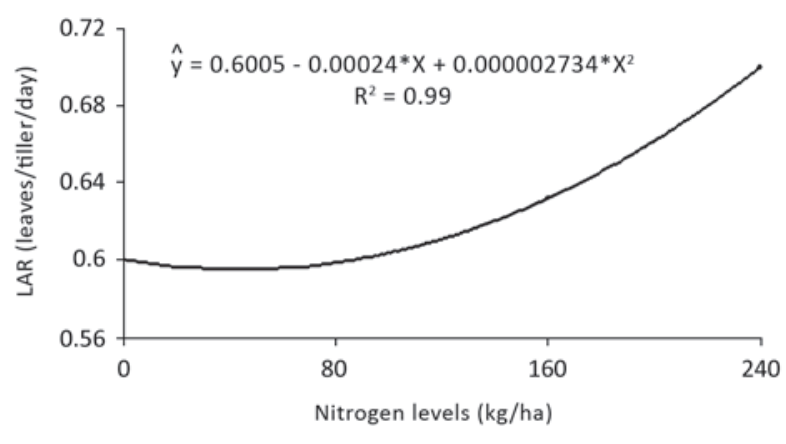

Figure 1 - Rate of the leaf appearance rate (LAR) of the B. brizantha cultivars in function of increasing nitrogen levels. $(* \mathrm{P}<0.05)$.

and increasing doses. According to Magalhães et al. (2007) phylochron indicates the time (in days or degree days) for the appearance of two consecutive leaves. More practically, it can be said that it indicates the time, in days, for the appearance of successive leaves.

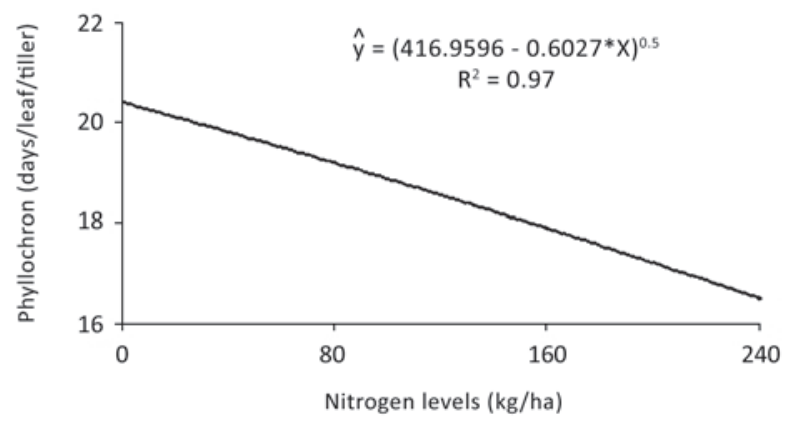

Figure 2 - Phyllochron rate of the $B$. brizantha cultivars in function of increasing nitrogen rates. $(* \mathrm{P}<0.05)$.

An increase in $\mathrm{N}$ supply causes a decrease in the interval of appearance of two consecutive leaves, i.e., the phyllochron rate. Therefore, this time reduction in days for the appearance of one leaf becomes a feature of extreme importance to seek the best form of management for grazing animals, because the increase of nitrogen fertilization on pasture reduces the time interval for its use, i.e., the grass recovers faster, making it available to animals at shorter intervals of rest, which in turn may represent an increased frequency of grazing, but in such a way that it does not compromise the sustainability of the pasture. This way, pasture management should allow an adequate harvest, by the animals, of the produced forage.
According to Silva et al. (2009), the results of this study, as well as the reported in literature, demonstrate the importance of nitrogen in reducing the time for the appearance of successive leaves, considering that it increases production of new cells, which have a positive impact on the number of leaves per plant.

Difference was found between the cultivars for variables leaf appearance rate and Phyllochron (Table I). Leaf appearance rate was greater for cv. Piatã when compared to cvs. Marandu and Xaraés, which did not differ for the same variables. This same trend was observed for the interval of appearance of two consecutive leaves, i.e., phyllochron.

When compared with the shortest time of appearance for the cv. Piatã, it is observed an average difference between five and six-day interval for the appearance of two consecutive leaves for cv. Marandu and cv. Xaraés due to this cultivar presenting, in a given time, a greater generation number of new leaves. In turn, it was reflected in the forage canopy. This may show that even among cultivars of the same species, there may be difference in their morphological and physiological characteristics and thus a particular cultivar can demonstrate superiority over the other cultivars.

Gomide and Gomide (2000) evaluating Panicum maximum cultivars, observed differences among cultivars and among tillers related to the leaf appearance, which is also evidenced in this work, in which the $B$. brizantha cultivars showed differences between themselves, showing that this variable may be influenced by genotype.

There was no effect of the interaction $(\mathrm{P}>$ 0.05 ) between $\mathrm{N}$ rates and cultivar on the variables leaf elongation rate (LER) and pseudostem elongation rate (PER), being the effect limited to the cultivar factor for both variables (Table I). Leaf elongation rate was not influenced by nitrogen fertilization, being observed an average of 0.83 $\mathrm{cm} /$ tiller/day for the appearance of new leaves. 
Rodrigues (unpublished data), studying Panicum maximum cultivars under NPK fertilization, found leaf elongation rate of $0.89 \mathrm{~cm} /$ tiller/day.

TABLE I

Leaf appearance rate (LAR) in leaves/tiller/day, phyllochronin day/leaf/tiller of $\boldsymbol{B}$. brizantha cultivars fertilized with increasing nitrogen rates, leaf elongation rate (LER) in cm/tiller/day and pseudostem elongation rate (PER) in cm/tiller/day of $B$. brizantha cultivars fertilized with increasing nitrogen rates.

\begin{tabular}{ccccc}
\hline \multirow{2}{*}{ Variables } & \multicolumn{3}{c}{ Cultivars } & \multirow{2}{*}{$*$ CV $(\%)$} \\
\cline { 2 - 4 } & Marandu & Piatã & Xaraés & \\
\hline LAR & $0.05 \mathrm{~b}$ & $0.07 \mathrm{a}$ & $0.05 \mathrm{~b}$ & 12.6 \\
Phyllochron & $19.93 \mathrm{a}$ & $14.87 \mathrm{~b}$ & $20.71 \mathrm{a}$ & 10.9 \\
LER & $0.77 \mathrm{~b}$ & $0.68 \mathrm{c}$ & $1.02 \mathrm{a}$ & 12.5 \\
PER & $0.12 \mathrm{~b}$ & $0.18 \mathrm{ab}$ & $0.22 \mathrm{a}$ & 46.9 \\
\hline
\end{tabular}

Means followed by same letter in the line do not differ $(\mathrm{P}>0.05)$ by Tukey test. ${ }^{*} \mathrm{CV}$ : coefficient of variation.

Pseudostem elongation rate was not influenced by nitrogen fertilization, averaging $0.17 \mathrm{~cm} /$ tiller/ day for the evaluated $\mathrm{N}$ rates, a result higher than that found by Fagundes et al. (2005), who evaluated Brachiaria decumbens and found an average pseudostem elongation rate of $0.14 \mathrm{~cm} /$ tiller/day.

These results observed for leaf elongation and pseudostem elongation rates differ from those found in several studies (Magalhães et al. 2007, Martuscello et al. 2005, Patês et al. 2007) which found an increased response of leaves and pseudostem growth rates with increasing $\mathrm{N}$ rates. However, corroborating the data from this experiment, Fagundes et al. (2006) evaluated signal grass in pasture fertilized with $\mathrm{N}$ and found no effect of it on pseudostem elongation rate.

Similar results for absence of $\mathrm{N}$ effect on pseudostem elongation rate were also observed by E.M.V. Porto (unpublished data) in evaluation of buffel grass and by Braz et al. (2008) in evaluation of tanzania grass.

According to Nabinger (1997), $\mathrm{N}$ does not exert great influence on the number of leaves on a tiller or on its elongation rate. Pinto et al. (1994) found that the $\mathrm{N}$ rates $(200$ and $600 \mathrm{~kg} / \mathrm{ha})$ did not affect the rates of elongation, appearance, leaf expansion and leaf area of guinea grass and setaria grass.

The results in literature about the relative pseudostem elongation rate have been rather contradictory (Braz et al. 2008, Patês et al. 2007).

Leaves elongation rate is a variable that correlates with morphogenic dry mass of forage, i.e., with the yield (Horst et al. 1978). But Nabinger and Pontes (2001) state that the leaf elongation is directly correlated with the leaf length, so when the results of this study were analyzed, it was found no difference in leaf blade final length (LBFL), obtaining an average of $23.15 \mathrm{~cm}$ between the evaluated rates for the variable leaf elongation rate, and that it probably might represent the lack of results obtained in the variable leaf elongation.

Leaf elongation and pseudostem elongation rates values varied $(\mathrm{P}<0.05)$ among cultivars. In Table I it can be observed that the highest yield found for the variables leaf elongation and pseudostem elongation rates was observed for cv. Xaraés. This cultivar also showed a higher value than the cv. Marandu, which in turn was superior to cv. Piatã for the variable leaf elongation rate, while for the variable pseudostem elongation rate, cv. Xaraés was superior to cv. Marandu, and cv. Piatã showed a value intermediate to the two cultivars. This shows that, even within the same species, it may occur the possibility of variation in the cultivar behavior, as seen in this study for the production of leaves and pseudostems.

The product of the ratio between leaf elongation rate and pseudostem elongation rate for the cultivars Marandu, Piatã and Xaraés indicates that for every centimeter of pseudostem elongation rate, there is an increase in leaf elongation rate of $6.42,3.78$ and $4.63 \mathrm{~cm}$, respectively.

There was no effect of the interaction ( $\mathrm{P}>$ 0.05 ) between factors $\mathrm{N}$ rates and cultivar on leaf blade final length (LBFL). According to Duru and Ducrocq (2000), the longer the stem, the greater the leaf blade final length. However; this relationship 
did not occur, and can be observed in the average value presented for each evaluated cultivar. It may be noted that there was no effect of $\mathrm{N}$ on pseudostem elongation rate and, therefore, it did not influence the leaf blade final length.

Therefore, what could be observed in this experiment was that there was no effect of $\mathrm{N}$ on pseudostem elongation rate and, therefore, it did not influence the leaf blade final length when the average of each cultivar is considered.

The lack of $\mathrm{N}$ effect on leaf blade final length differs from results found in several studies (Garcez Neto et al. 2002, Alexandrino et al. 2004) who found a positive linear effect of $\mathrm{N}$ on leaf blade final length. However, corroborating the data from this experiment, E.M.V. Porto (unpublished data) also found no interaction between $\mathrm{N}$ rates and buffel grass cultivars for the variable leaf blade final length.

For the B. brizantha cultivars, leaf blade final length values did not differ $(\mathrm{P}>0.05)$ among themselves, with average values of 20.96, 21.55 and $26.92 \mathrm{~cm} /$ tiller for the cvs. Marandu, Piatã and Xaraés, respectively. However, values were higher than those found by Marcelino et al. (2006), who found an average leaf blade final length of $19.22 \mathrm{~cm}$ for Marandu grass under field conditions evaluation.

For Lemaire (1997) this variable is of fundamental importance for the efficiency of pasture productivity, since the changes that occur in the forage plant morphology, as well as in pasture structure, due to the number of green leaves per tiller and the leaf final length, expresses the maximum number of green leaf tissue per tiller.

\section{CONCLUSIONS}

The morphogenetic characteristic leaf appearance rate responds positively to nitrogen fertilization, while phylochron responds negatively.

The rate equivalent to $240 \mathrm{~kg} / \mathrm{ha}$ of $\mathrm{N}$ corresponds to a higher leaf appearance rate for all evaluated B. brizantha cultivars (cv. Marandu, cv. Piatã and cv. Xaraés).
The cultivars are different considering the variables leaf appearance rate, phylochron, leaf elongation rate and pseudostem elongation rate.

The cultivar Marandu has a higher ratio between leaf elongation rate and pseudostem elongation rate, which favors higher quality forage.

The cultivar Piatã has higher leaf appearance rate in a shorter period of time in relation to others.

\section{ACKNOWLEDGMENTS}

The Coordenação de Aperfeiçoamento de Pessoal de Nível Superior (CAPES) and the Fundação de Amparo à Pesquisa do Estado de Minas Gerais (FAPEMIG) for financial support.

\section{RESUMO}

Este estudo teve como objetivo avaliar as características morfogênicas de três cultivares de Brachiaria brizantha submetidos à adubação nitrogenada. $\mathrm{O}$ delineamento foi em blocos casualizados em esquema fatorial $4 \times 3$; três cultivares de B. brizantha - Marandu, Piatã, Xaraés e quatro níveis de nitrogênio - 0, 80,160 e $240 \mathrm{~kg} / \mathrm{ha}$, com três repetições. As unidades experimentais constaram de vasos plásticos preenchidos com $5 \mathrm{dm} 3$ de solo. Logo após a adubação de estabelecimento, as três variedades foram semeadas diretamente nos vasos, deixando, após o desbaste, cinco plantas por vaso. Quarenta e cinco dias após o plantio, foi feita uma padronização de corte de 10 $\mathrm{cm}$ de altura. As doses de nitrogênio foram distribuídas de acordo com os tratamentos, divididas em três aplicações. As características morfogênicas foram avaliadas em três perfilhos por unidade de amostragem e os dados foram submetidos à análise de variância e regressão. Para todas as características avaliadas, não houve interação entre os fatores cultivar e doses de nitrogênio, verificando-se apenas os efeitos do nitrogênio sobre a taxa de aparecimento foliar e filocrono. A dose de $240 \mathrm{~kg}$ /ha de $\mathrm{N}$ corresponde à maior taxa de aparecimento foliar. O cultivar Marandu apresenta maior relação lâmina foliar: pseudocolmo e razão entre taxa de alongamento foliar e alongamento de pseudocolmo, favorecendo a melhor qualidade da forragem. 
Palavras-chave: cv. Marandu, cv. Piatã, cv. Xaraés, morfogênese, capim-braquiária.

\section{REFERENCES}

ALeXANdrino E, NASCIMENTO JÚNIOR D, MOSQUim PR, REGAZZI AJ AND RochA FC. 2004. Características morfogênicas e estruturais na rebrotação da Brachiaria brizantha cv. Marandu submetida a três doses de nitrogênio. R Bras Zootec 33: 1372-1379.

Braz TG dos S, Freitas FP, Martuscello JA, SANtos Mer, Pimentel RM AND FonseCA DM. 2008. Características morfogênicas e estruturais de capimtanzânia submetido a doses de nitrogênio e densidades de plantas. In: Reunião da Sociedade Brasileira de Zootecnia, 45, Anais..., SBZ.1 CD-ROM.

CFSEMG - COMISSÃo DE FERTILIDADE DO SOlO DO EsTAdO DE MinAS GERAIS. 1999. Recomendações para o uso de corretivos e fertilizantes em Minas Gerais: $5^{\text {a }}$ aproximação. UFV, $359 \mathrm{p}$.

Chapman DF AND Lemaire G. 1993. Morphogenetic and structural determinants of plant regrowth after defoliation. In: BAKER MJ (Ed), Grasslands for our world. SIR Publishing, p. 55-64.

Duru M AND DucrocQ H. 2000. Growth and senescence of the sucessive leaves on tiller. Ontogenic development and effect of temperature. Ann Bot-London 85: 635-643.

FAGUNDES JL, FONSECA DM, GOMIDE JA, NASCIMENTO Jr D, Vitor CMT, Moraes RV, Mistura C, Reis GC AND MARTUSCELLO JA. 2005. Acúmulo de forragem em pastos de Brachiaria decumbens adubados com nitrogênio. Pes Agropec Bras 40: 397-403.

FAGUNDES JL, FonseCA DM DA, Mistura C, MORAIS RV DE, VITOR CMT, GOMIDE JA, JUNIOR DN, CASAGRANDE DR AND COSTA LT. 2006. Características morfogênicas e estruturais do capim-braquiária em pastagem adubada com nitrogênio avaliadas nas quatro estações do ano. $\mathrm{R}$ Bras Zootec 35: 21-29.

GARCEZ Neto AF, Júnior DN, Regazzi AJ, FonsecA DM, MosQuim PR AND GOBBI KF. 2002. Respostas Morfogênicas e Estruturais de Panicum maximum cv. Mombaça sob diferentes níveis de adubação nitrogenada e alturas de corte. R Bras Zootec 31: 1890-1900.

Gomide AM AND Gomide JA. 2000. Morfogênese de Cultivares de Panicum maximum Jacq. R Bras Zootec 29: 341-348.
Horst GL, NELSON CJ AND ASAY KH. 1978. Relationship of leaf elongation to forage yield of tall fescue genotypes. Crop Science 18: 715-719.

LEMAIRE G. 1997. The physiology of grass growth under grazing: tissue turnover. In: SIMPÓSIOINTERNACIONAL SOBRE PRODUÇÃO ANIMAL EM PASTEJO, 1997. Viçosa, MG. Anais... Viçosa, p. 115-144.

Magalhães AF, Pires AJV, Carvalho GGP, Silva FF, SOUSA RS AND VELOSO CM. 2007. Influência do nitrogênio e do fósforo na produção do capim-braquiária. R Bras Zootec 36: 1240-1246.

Marcelino KRA, NASCIMENTO JUNIOR D, SILVA SC, EuClides VPA AND FonseCA DM. 2006. Características morfogênicas e estruturais e produção de forragem do capim-marandu submetido a intensidades e freqüências de desfolhação. R Bras Zootec 35: 1590-1516.

Martuscello JA, Fonseca DM, Nascimento Júnior D, SANTOS PM, RIBEIRO JUNIOR JI, CUNHA DNFV AND MOREIRA LM 2005. Características morfogênicas e estruturais do capim-xaraés submetido à adubação nitrogenada e desfolhação. R Bras Zootec 34: 1475-1482.

NABINGER C. 1997. Princípios da exploração intensiva de pastagens. In: SIMPÓSIO SOBRE MANEJO DA PASTAGEM: PRODUÇÃO DE BOVINOS A PASTO, 13, Anais... FEALQ, p. 15-96.

NABINGer C And Pontes L DA S. 2001. Morfogênese de plantas forrageiras e estrutura do pasto. In: REUNIÃO DA SOCIEDADE BRASILEIRA DE ZOOTECNIA, 38, Anais... SBZ, p. 755-771.

PATÊS NMS, PIRES AJV, Silva CCF, SANTOS LC, CARVAlHo GGP AND FREIRE MAL. 2007. Características morfogênicas e estruturais do capim-tanzânia submetido a doses de fósforo e nitrogênio. R Bras Zootec 36: 1736-1741.

Pinto JC, Gomide JÁ And Maestri M. 1994. Produção de matéria seca e relação folha/caule de gramíneas forrageiras tropicais, cultivadas em vasos, com duas doses de nitrogênio. R Bras Zootec 23: 313-326.

Silva CCF DA, BONOMO P, PIRES AJV, MARANHÃo CMA, PATÊS NMS AND SANTOS, LC. 2009. Características morfogênicas e estruturais de duas espécies de braquiária adubadas com diferentes doses de nitrogênio. R Bras Zootec 38: 657-661.

VAlle CB, Euclides VPB AND Macedo MCM. 2001. Características das plantas forrageiras do gênero Brachiaria. In: SIMPÓSIO SOBRE MANEJO DE PASTAGEM, 17, Piracicaba. Anais... Piracicaba: FEALQ, p. 21-64. 